\title{
Penipuan Dalam Jual Beli Online: Perspektif Hukum Telematika
}

\section{Muhammad Kamran ${ }^{1}$, Maskun ${ }^{2}$}

1, 2 Fakultas Hukum Universitas Hasanuddin, Makassar, Indonesia

@ : muhammadkamran030196@gmail.com ${ }^{1}$

xxxxxxxxxxxxx

Dikirim: 07/01/2021

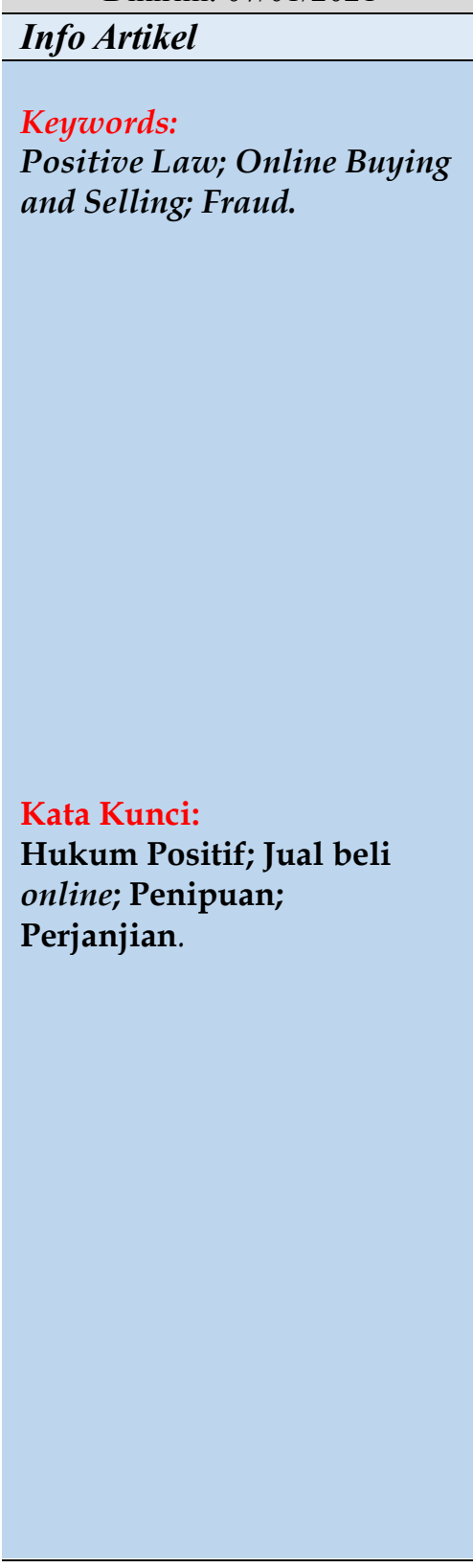

Direvisi: 14/02/2021

Abstract
Introductioan: The current proliferation of online buying and selling is
also followed by the high risk of online fraud.
Purposes of the Research: Know and understand the legal effects of
fraud in online buying and selling agreements in the Indonesian positive
law.
Methods of the Research: This research is a normative legal research. It
applied some approaches such as a statutory approach, a case approach, a
conceptual approach, an analytical approach, and a theoretical approach.
The legal materials used were qualified as a primary, secondary, and
tertiary legal materials. They were then analysed with qualitatively with
deductive and inductive methods.
Results of the Research: The legal consequence of fraud in online
buying and selling agreements in the Indonesian positive law creates
responsibility for consumer losses in electronic transactions as regulated
by those regulations. For losses of the consumer, the person, who due to
his/her fault published the loss, should compensate the loss.

\section{A. PENDAHULUAN}

Kejahatan bukanlah konsep baru dalam sejarah peradaban manusia. Sejak manusia diciptakan yang dimulai dengan tindakan pembangkangan Iblis terhadap perintah Allah 
untuk memberi penghormatan terhadap makhluk ciptaan Allah lainnya yang disebut manusia. Pembangkangan ini kemudian diteruskan dengan janji Iblis untuk selalu menggoda manusia hingga akhir zaman ${ }^{1}$. Konflik kepentingan antara manusia dan iblis dipandang sebagai embrio kejahatan yang bermula dari perasaan iri, sombong, dan dengki. ${ }^{2}$

Pada tahapan perkembangannya, modus operasi kejahatan bergerak maju seiring perkembangan peradaban manusia ${ }^{3}$. Sejalan dengan perkembangan masyarakat dan teknologi, manusia semakin tinggi memanfaatkan fasilitas teknologi digital, untuk berinteraksi antara individu yang satu dengan individu yang lain ${ }^{4}$. Hampir semua aktivitas perekonomian di dunia memanfaatkan media internet dengan menggunakan sarana sistem elektronik. Salah satu segi aktivitas ekonomi yaitu transaksi dengan memanfaatkan dunia internet yang populer dikenal dengan perdagangan melalui media internet (e-commerce) ${ }^{5}$. Kemajuan dunia internet melahirkan suatu dunia modern yang populer dikenal dengan dunia internet, di mana dalam dunia internet individu yang satu dengan individu yang lain bisa berinteraksi tanpa batas wilayah dan dilakukan tanpa bertemu muka secara langsung tetapi dilakukan melalui transaksi elektronik ${ }^{6}$.

Di Indonesia kehadiran teknologi informasi telah diundangkan UU No. 11 Tahun 2008 tentang Informasi dan Transaksi Elektronik dan UU No. 19 Tahun 2016 sebagaimana diubah dengan UU No. 11 Tahun 2008 tentang Informasi dan Transaksi Elektronik (selanjutnya disingkat UU ITE). UU ITE merupakan payung hukum pertama untuk mengatur adanya aktifitas transaksi elektronik di Indonesia, dan memberikan pembaruan hukum dengan tujuan menjamin kepentingan masyarakat akan jaminan kepastian hukum untuk bertransaksi dengan memanfaatkan media elektronik.

Perikatan atau populer disebut kontrak memiliki fungsi begitu berarti pada kehidupan masyarakat sosial khususnya dalam dunia perdagangan ${ }^{7}$. Pada umum perjanjian telah lahir pada saat terjadinya persesuaian kehendak para pihak tentang unsur esensial atau hal yang pokok dari perjanjian tersebut. Seperti contoh, seandainya pada perjanjian jual beli sudah terjadinya kesepakatan mengenai "barang dan harga," lahirnya perjanjian, sebaliknya segala sesuatu yang belum diperjanjikan untuk para pihak hendaknya ditentukan oleh undangundang ${ }^{8}$. Perjanjian jual beli, khususnya jual beli barang bergerak merupakan perjanjian yang bersifat konsensual, yakni mengikat pada saat terjadinya kesepakatan, walaupun harganya belum dibayar dan barangnya belum diserahkan?

\footnotetext{
1 Maskun et al., Korelasi Kejahatan Siber Dan Kejahatan Agresi Dalam Perkembangan Hukum Internasional (Makassar: Nas Media Pustaka, 2020), h. 1.

2 Maskun et al.

3 Maskun et al.

4 Syaibatul Hamdi, Suhaimi, and Mujibussalim, "Bukti Elektronik Dalam Sistem Pembuktian Pidana," Jurnal Ilmu Hukum 1, no. 4 (2013): 25-31, http:/ /jurnal.unsyiah.ac.id/MIH/article/view/4564. h. 25.

5 Rahadi Wasi Bintoro, "Penerapan Hukum Dalam Penyelesaian Sengketa Transaksi Elektronik Di Peradilan Umum," Jurnal Dinamika Hukum 11, no. 2 (2011): 258-72, https://doi.org/10.20884/1.jdh.2011.11.2.185, h. 259.

6 Aloina Sembiring Meliala, “Analisis Yuridis Terhadap Legalitas Dokumen Elektronik Sebagai Alat Bukti Dalam Penyelesaian Sengketa," Jurnal Wawasan Yuridika 32, no. 1 (2015): 99-111, https://doi.org/10.25072/jwy.v32i1.92, h. 100.

7 HS Salim, Teknik Pembuatan Akta Perjanjian (TPA Dua) (Jakarta: Rajawali Pers, 2018), h. 1.

8 Ahmadi Miru, Hukum Kontrak \& Perancangan Kontrak (Jakarta: Rajawali Pers, 2018), h. 13.

9 Ahmadi Miru and Sakka Pati, Hukum Perjanjian (Penjelasan Makna Pasal-Pasal Perjanjian Bernama Dalam BW) (Jakarta: Sinar Grafika, 2020), h. 3.
} 
Meskipun ditegaskan bahwa perjanjian lahir pada saat tercapainya kesepakatan mengenai hal pokok dalam kontrak tersebut, akan tetapi, ada beberapa hal yang mesti diketahui, yakni syarat sahnya perjanjian sebagaimana diatur dalam Pasal 1320 BW, yaitu ${ }^{10}$ :

a) kesepakatan mereka yang mengikatkan dirinya;

b) kecakapan untuk membuat suatu perjanjian;

c) suatu pokok persoalan tertentu; dan

d) suatu sebab yang tidak terlarang.

Keempat syarat tersebut populer disebut dengan "sepakat, cakap, hal tertentu, dan sebab yang halal. Selanjutnya Keempat unsur tersebut, pada doktrin ilmu hukum yang berkembang, digolongkan ke dalam ${ }^{11}$ :

1) dua unsur utama yang berkenaan subjek (pihak) yang melahirkan perjanjian (unsur subjektif), dan;

2) dua unsur utama lainnya yang berkaitan langsung mengenai objek perjanjian (unsur objektif).

Syarat-syarat tersebutlah yang wajib dipenuhi oleh setiap pihak dalam pembuatan perjanjian. Jika salah satu syarat tidak terpenuhi perjanjian tersebut dapat dibatalkan dan batal demi hukum ${ }^{12}$.

Contoh kasus penipuan perjanjian jual beli online adalah kasus yang terjadi di Kabupaten Barru Provinsi Sulawesi Selatan pada tahun 2020, di mana dalam kronologis kasusnya korban F dan pelaku NBH telah melakukan kesepakatan lewat media online untuk transaksi jual beli masker sensi yang telah diunggah pelaku lewat aplikasi media sosial facebook, kemudian pelaku dan korban mulai saling tawar menawar melalui aplikasi messenger, korban dan pelaku sepakat mengenai harga Rp. 170.000/box dengan memesan masker sebanyak 15 box dengan harga Rp. 2.550.000, kemudian korban chatting lagi lewat whatsApp dan pelaku mengirim nomor rekening ke korban. Akan tetapi, setelah korban mengirimkan uang terhadap si pelaku dengan lunas sesuai dengan harga barang yang dipesan, pada saat uang sampai di tangan pelaku, pelaku pun membuat paket berupa satu kotak berisi buku tulis dan handuk bayi bekas, dengan tampilan rapi kemudian pelaku menarik uang transfer Rp. 2.550.000 lalu menuju ke tempat pengiriman barang di Kota Parepare bersama istrinya, tidak berselang beberapa menit kemudian pelaku memblokir nomor whatsApp dan akun facebook korban, dalam kasus ini korban mengalami kerugian dan melaporkan kejadian ini ke Polres Kabupaten Barru dan dalam kasus ini pihak kepolisian telah berhasil mengungkap kasus penipuan perjanjian jual beli online dengan barang bukti yang diamankan satu buah handphone merek Oppo warna gold, kartu handphone satu, dos dengan tampilan rapi, buku, serta selimut bayi bekas dan uang Rp. $450.000,-. .13$

Kasus kedua sekira-kiranya pada bulan Februari 2016 ditemukan di Kabupaten Sidrap Provinsi Sulawesi Selatan pada tahun 2016, Sub Direktorat Cyber Crime Dit Reserse Kriminal Khusus Polda Metro Jaya meringkus kelompok penipuan online dengan menggunakan akun

\footnotetext{
10 Miru and Pati.

${ }^{11}$ Kartini Muljadi and Gunawan Widjaja, Perikatan Yang Lahir Dari Perjanjian (Jakarta: Rajawali Pers, 2014), h. 93 .

12 Andika Prawira Buana et al., “Implikasi Pelaksanaan Perjanjian Jual Beli Telepon Seluler Ilegal (Black Market)," JCH (Jurnal Cendekia Hukum) 6, no. 1 (2020): 124-33, https://doi.org/10.33760/jch.v6i1.287, h. 127.

13 NewsMetropol, "Polres Barru Ungkap Kasus Penipuan Transaksi Jual Beli Online," newsmetropol.com, 2020, https://newsmetropol.com/polres-barru-ungkap-kasus-penipuan-transaksi-jual-beli-online/\#.
} 
palsu yang ada di beberapa toko online ternama di Indonesia, Kelompok tersebut membuat akun palsu di toko online, di antaranya olx.co.id, kaskus.co.id, bukalapak.com, tokopedia.com dan lain-lain, menurut keterangan Direktur Reskrimsus Polda Metro Jaya Komisaris Besar dalam keterangan pers di Mapolda Metro Jaya di mana ada sekelompok penipu yang berkedok menawarkan sepeda motor, jam tangan, batu akik, mobil dan telepon genggam melalui berbagai akun palsu di toko online akhirnya dibekuk polisi. Modusnya adalah setelah korban mentransfer uang, kelompok tersebut langsung mengambil uang dan barang yang dipesan oleh korban tidak dikirimkan, karena pada dasarnya barang tersebut tidak pernah ada, Lima orang diringkus, yakni H (34), AS (23), Z (49), R (33), dan B (32), kelimanya ditangkap di kawasan Sidrap Sulawesi Selatan. Selain tersangka polisi juga mengamankan sejumlah barang bukti kejahatan di antaranya 14 buah telepon genggam, 32 rekening berbagai bank, satu unit laptop, satu Mobil Honda CRV, satu Mobil Honda Freed, dan sebuah Sepeda Motor Yamaha, di mana total kerugian korban mencapai Rp. 10,1 Miliar ${ }^{14}$.

Berdasarkan kasus tersebut di atas, ditemukan fakta hukum bahwa perjanjian jual beli online rawan terjadinya penipuan, tentunya ini terjadi karena aktivitas perjanjian jual beli online tidak ada aktivitas pertemuan secara langsung dan kadang di antara para pihak tidak saling mengenal, sehingga hal ini rawan terjadinya penipuan, jika melihat contoh kasus di atas, maka tunduk pada Pasal 1320 BW yaitu syarat sahnya perjanjian, yaitu kesepakatan, kecakapan, suatu pokok persoalan tertentu, dan suatu sebab yang tidak terlarang. Sehingga dengan tunduknya pada Pasal 1320 BW maka seandainya salah satu pihak melanggarnya, tentu akan muncul konsekuensi hukum adalah perjanjian dapat dimohonkan pembatalan dan batal demi hukum, selain konsekuensi hukum perdata di atas juga berdampak pada konsekuensi hukum pidana penipuan dan UU ITE yang berlaku positif di Indonesia.

Isu hukum berdasarkan kasus tersebut di atas, ditemukan fakta hukum bahwa dalam perjanjian jual beli online masih rawan terjadinya penipuan, masalah hukum yang sering kejadian pada penipuan perjanjian jual beli online, misalnya pembeli sudah membayar harganya tetapi penjual tidak mengirim barang sampai waktu yang lama bahkan tidak sampai, karena barang tersebut memang tidak pernah ada sebelumnya, barang yang sampai ke pembeli rusak atau tidak sebagaimana mestinya sehingga pembeli tidak memakainya. Berdasarkan masalah hukum tersebut di atas, rawan terjadinya penipuan karena perjanjian jual beli online tidak dilakukan pertemuan langsung dan para pihak kadang tidak saling mengenal. Sehingga para subjek hukum dalam perjanjian jual beli online tanpa bertemu dan begitu pula dengan objek yang diperjanjikan dalam jual beli. Sehingga hal ini menimbulkan rawan terjadinya penipuan dalam jual beli online.

Dalam jual beli online, masyarakat dapat melakukan perjanjian jual online lewat sebuah perusahaan e-commerce terkemuka di Indonesia baik Tokopedia, Lazada, Blibli.com, Bukalapak, Zalora, Shopee, Berrybenka, Kaskus dan Traveloka, yang tentunya perusahaan terkemuka perdagangan online (e-commerce) atau marketplace besar di Indonesia yang telah memiliki sistem yang terstruktur rapi untuk mencegah terjadinya rawan penipuan sehingga cenderung lebih aman, dibandingkan dengan jual beli online baik facebook, messenger, telegram, whatsApp, instagram, twitter, forum yang tentunya risiko sangat besar terjadi rawan penipuan karena situs jual beli online bukan sebuah perusahaan e-commerce terkemuka di Indonesia

14 Dewi Setyowati, Candra Pratama Putra, and Ramdhan Dwi Saputro, "Perlindungan Hukum Pada Tindak Pidana E-Commerce," Perspektif Hukum 18, no. 2 (2019): 215-46, https:/ / doi.org/10.30649/phj.v18i2.160, h. 220.

44| B A L OBE Law Journal Vol.1 No. 1, April 2021 
yang tentunya tidak memiliki sistem yang terstruktur rapi untuk mencegah terjadinya rawan penipuan sehingga cenderung tidak terlalu aman terhadap penipuan.

Sebagaimana diketahui pengaturan hukum yang telah mengatur masalah penipuan dalam perjanjian jual beli online dalam hukum positif Indonesia yaitu baik pengaturan tentang transaksi elektronik yang diatur dalam UU No. 11 Tahun 2008 tentang Informasi dan Transaksi Elektronik dan UU No. 19 Tahun 2016 tentang Perubahan atas UU No. 11 Tahun 2008 tentang Informasi dan Transaksi Elektronik sebagai dasar utama pengaturan jual beli online, Peraturan Pemerintah Republik Indonesia Nomor 71 Tahun 2019 Tentang Penyelenggaraan Sistem dan Transaksi Elektronik. Akan tetapi, dengan adanya pengaturan hukum tersebut tetapi fakta di dalam masyarakat masih ditemukan rawan terjadinya penipuan dalam jual beli online. Hal ini disebabkan Karena penegak hukum belum cukup mampu menerapkan dengan baik pengaturan hukum tersebut untuk mengantisipasi, mengoptimalkan atau menekan terjadinya persoalan-persoalan hukum yang sering terjadi dalam jual beli online, yaitu utamanya persoalan penipuan dalam jual beli online yang masih rawan terjadinya penipuan.

Dengan perkembangan masyarakat dan teknologi, telah terjadi perubahan gaya hidup dan perilaku masyarakat dunia yang awalnya perjanjian jual beli berbentuk konvensional (tertulis dan lisan) kini telah mengalami perkembangan dengan munculnya perjanjian atau kontrak elektronik. Akan tetapi, dengan munculnya perkembangan perjanjian atau kontrak elektronik, yang semula perjanjian jual beli dengan tatap muka (konvensional) kini telah beralih dengan perjanjian jual beli online, perjanjian jual beli online dalam hal ini tanpa dilakukan secara langsung tetapi lewat media online tanpa dilakukan pertemuan secara langsung, maka dengan beralih proses transaksi jual beli tersebut maka risiko terjadinya masalah-masalah hukum semakin meningkat, misalnya rawan terjadinya penipuan, wanprestasi, kekhilafan atau kesesatan dalam transaksi jual beli online.

\section{B. METODE PENELITIAN}

Tipe penelitian dipergunakan untuk penelitian ini merupakan "tipe penelitian hukum doktrinal" ataupun "penelitian hukum normatif (normative legal research)" ${ }^{15}$. Penelitian normatif adalah penelitian hukum kepustakaan yang di Negara-negara yang sudah lazim disebut "Legal Research" atau "Legal Research Instruction,"16 dengan Pendekatan Perundangundangan (Statute Approach), Pendekatan Kasus (Case Approach), Pendekatan Konseptual, Pendekatan Analitis (Analytical Approach), Pendekatan Teori (Theoretical Approach) ${ }^{17}$. Jenis dan sumber bahan hukum yaitu bahan hukum primer, merupakan bahan hukum yang bersumber pada Kitab Suci maupun bahan hukum yang bersumber dari berbagai peraturan perundang-undangan, yakni Undang-Undang Dasar Negara Republik Indonesia tahun 1945, UU No. 11 Tahun 2008 tentang Informasi dan Transaksi Elektronik, UU No. 19 Tahun 2016 tentang perubahan atas UU No. 11 Tahun 2008 tentang Informasi dan Transaksi Elektronik. Peraturan Pemerintah Nomor 71 Tahun 2019 tentang Penyelenggaraan Sistem dan Transaksi Elektronik, bahan hukum sekunder, merupakan berbagai referensi ataupun karya-karya

15 Syahruddin Nawi, Penelitian Hukum Normatif Versus Penelitian Hukum Empiris (Makassar: Umitoha Ukhuwah Grafika, 2018), h. 7.

16 Soerjono Soekanto and Sri Mamudji, Penelitian Hukum Normatif, Suatu Tinjauan Singkat, Jakarta: Raja Grafindo Persada (Jakarta: Rajawali Pers, 2015), 23.

17 Irwansyah, Penelitian Hukum (Pilihan Metode E Praktik Penulisan Artikel) (Yogyakarta: Mirra Buana Media, 2020), h. 133.

$45 \mid$ B A L OBE Law Journal Vol. 1 No.1, April 2021 
ilmiah bidang hukum, berupa buku hukum, artikel hukum, jurnal hukum, naskah pidato pengukuhan guru besar bidang hukum, naskah orasi ilmiah dibidang hukum dan naskahnaskah akademik bidang hukum, naskah hukum hasil lokakarya dan sebagainya, bahan hukum tersier, merupakan bahan hukum yang sifatnya pelengkap, yakni melengkapi dua bahan yang lain yakni bahan hukum primer dan bahan hukum sekunder. Bahan hukum tersier misalnya kamus-kamus umum, kamus hukum maupun terminologi hukum yang menjadi dasar untuk seorang peneliti di bidang hukum dalam menelusuri makna dan arti sebuah kata atau kalimat yang berhubungan dengan bidang hukum, termasuk juga ensiklopedia. ${ }^{18}$ Teknik pengumpulan bahan hukum yang digunakan pada penelitian ini berdasarkan pengamatan maupun penelusuran cermat terhadap berbagai bahan hukum sebagaimana disebutkan di atas, yakni penelusuran bahan hukum primer, bahan hukum sekunder maupun bahan hukum tersier ${ }^{19}$. Analisis bahan hukum yang digunakan dalam penelitian ini merupakan jenis analisis kualitatif, analisis kualitatif kebanyakan dipergunakan pada tipe penelitian hukum dengan karakteristik penelitian hukum normatif yang datanya berasal dari kepustakaan, berupa bahan-bahan hukum, seperti bahan hukum primer, bahan hukum sekunder maupun bahan hukum tersier ${ }^{20}$. Mengenai analisis yuridis normatif pada esensinya memfokuskan pada metode deduktif untuk pegangan utama, dan metode induktif sebagai tata kerja penunjang. Analisis normatif utamanya menggunakan bahan-bahan kepustakaan sebagai sumber data penelitiannya ${ }^{21}$.

\section{HASIL DAN PEMBAHASAN}

Pada dunia internet, banyak berlangsung transaksi pada aspek hukum bisnis. Salah satu aktivitas yang selalu dilaksanakan, yaitu aktivitas perdagangan. Karena aktivitas perdagangan tersebut, hadirlah suatu sistem transaksi perdagangan yang dilaksanakan dalam dunia internet yang dikenal dengan e-commerce ${ }^{22}$. Dunia perdagangan atau bisnis yang berkembang cepat mengusulkan sebuah bentuk atau sistem perdagangan yang inovatif dan kreatif mengikuti perkembangan teknologi yang tinggi di bidang media komunikasi dan informasi. Bentuk ini tentunya juga dipahami sebagai konstruksi terhadap bentuk perjanjian "klasik" yang selama ini populer, meskipun berbeda secara bentuk. Namun, secara substansi tetaplah sama dengan sentuhan modifikasi ${ }^{23}$.

E-commerce pada dasarnya merupakan model transaksi jual beli modern yang mengaplikasikan inovasi teknologi seperti internet sebagai media transaksi. Kehendak para pihak yang diwujudkan dalam kesepakatan ialah merupakan dasar mengikatnya suatu perjanjian, kehendak itu dapat dinyatakan dengan berbagai cara baik lisan maupun tertulis

18 Nawi, Penelitian Hukum Normatif Versus Penelitian Hukum Empiris. h. 31.

19 Nawi. h. 251.

2017), h. 53.

${ }^{20}$ Nurul Qamar et al., Metode Penelitian Hukum (Legal Research Methods) (Makassar: Social Political Genius, h. 166.

${ }^{21}$ Amiruddin and Zainal Asikin, Pengantar Metode Penelitian Hukum (Jakarta: Raja Grafindo Persada, 2018),

22 Meliala, “Analisis Yuridis Terhadap Legalitas Dokumen Elektronik Sebagai Alat Bukti Dalam Penyelesaian Sengketa." h. 100

${ }^{23}$ Maskun, Kejahatan Siber Cyber Crime Suatu Pengantar (Jakarta: Kencana Prenada Media Group, 2013), h. 18.

$46 \mid$ B A LOBE Law Journal Vol. 1 No. 1, April 2021 
dan mengikat para pihak dengan segala akibat hukumnya ${ }^{24}$.

Suatu transaksi e-commerce juga merupakan suatu perjanjian jual beli yang sama dengan jual beli konvensional pada umumnya, dalam suatu transaksi $e$-commerce juga mengandung suatu asas konsensualisme, yang berarti kesepakatan dari kedua belah pihak. Suatu kesepakatan terjadi apabila terdapat suatu penawaran dari pihak penjual lalu ada suatu penerimaan dari pihak calon pembeli. Penawaran dan penerimaan inilah yang merupakan awal terjadinya kesepakatan antara pihak-pihak yang bersangkutan ${ }^{25}$.

Salah satu kelebihan atau keuntungan dalam e-commerce adalah informasi yang beragam dan mendetail yang dapat diperoleh konsumen dibandingkan dengan perdagangan konvensional tanpa harus bersusah payah pergi ke banyak tempat. Namun demikian, $e-$ commerce juga memiliki kelemahan. Metode transaksi elektronik yang tidak mempertemukan pelaku usaha dan konsumen secara langsung serta tidak dapatnya konsumen melihat secara langsung barang yang dipesan berpotensi menimbulkan permasalahan yang merugikan konsumen ${ }^{26}$.

Transaksi jual beli online memang mudah dan cepat tanpa pertemuan secara langsung dengan penjual, tetapi pembeli tidak dapat melihat langsung kondisi barang yang ingin dibeli. Jika dalam transaksi tersebut terdapat penipuan atau pihak penjual melakukan suatu wanprestasi, maka dapat dikenakan sanksi yang sesuai. Sehingga konsumen mendapat perlindungan hukum yang jelas ${ }^{27}$.

O.C Kaligis mengemukakan pendapat bahwa:

"Perjanjian e-commerce yang dilakukan tanpa pertemuan yang secara langsung tetaplah sah menurut hukum dan menimbulkan hak dan kewajiban bagi kedua belah pihak."

Menurut analisis penulis, walaupun perjanjian jual beli lewat transaksi elektronik tidak dilakukan pertemuan langsung dan para pihak kadang tidak saling mengenal. Sehingga para subjek hukum dalam perjanjian jual beli lewat transaksi elektronik tanpa bertemu dan begitu pula dengan objek yang diperjanjikan dalam jual beli, tetapi perjanjian tersebut yang dilakukan tanpa pertemuan secara langsung tetaplah sah menurut hukum dan menimbulkan hak dan kewajiban bagi kedua belah pihak, sepanjang perjanjian tersebut telah memenuhi syarat sah perjanjian 1320 BW maupun ketentuan yang diatur dalam UU ITE dengan PP No. 71 Tahun 2019, dan perjanjian tersebut tidak dilarang oleh undang-undang dan tidak bertentangan dengan kesusilaan baik atau dengan ketertiban umum. Akan tetapi, apabila adanya unsur penipuan perjanjian jual beli lewat online maka akan memunculkan akibat hukum, baik akibat hukum pidana maupun hukum perdata.

Pendapat penulis di atas, dikuatkan pula peraturan perundang-undangan dalam Pasal 46 PP No 71 Tahun 2019 diatur bahwa:

\footnotetext{
${ }^{24}$ S Putra, "Perlindungan Hukum Terhadap Konsumen Dalam Transaksi Jual-Beli Melalui E-Commerce," Jurnal Ilmu Hukum 4, no. 1 (2014): 287-308, https:/ /media.neliti.com/media/publications/9164-ID-perlindunganhukum-terhadap-konsumen-dalam-transaksi-jual-beli-melalui-e-commerc.pdf, h. 291.

25 Sukarmi and Yudhi Tri Permono, "Perlindungan Hukum Konsumen Dalam Transaksi Secara Online," Jurnal Hukum 35, no. 1 (2019): 77-100, https://doi.org/10.26532/jh.v35i1.11046, h. 88.

26 Yudha Sri Wulandari, "Perlindungan Hukum Bagi Konsumen Terhadap Transaksi Jual Beli ECommerce," Ajudikasi : Jurnal Ilmu Hukum 2, no. 2 (2018): 199-210, https:/ / doi.org/10.30656/ajudikasi.v2i2.687, h. 205.

27 Basyirah Mustarin, “Tinjauan Hukum Nasional Dan Hukum Islam Terhadap Konsumen Pengguna Jasa Jual Beli Online," Jurnal Restorative Justice 1, no. 2 (2017): 132-45, https:/ / doi.org/10.35724/jrj.v1i2.1915, h. 137.
} 
1. “Transaksi Elektronik dapat dilakukan berdasarkan Kontrak Elektronik atau bentuk kontraktual lainnya sebagai bentuk kesepakatan yang dilakukan oleh para pihak;

2. Kontrak Elektronik dianggap sah apabila:
a. terdapat kesepakatan para pihak;
b. dilakukan oleh subjek hukum yang cakap atau yang berwenang mewakili sesuai dengan ketentuan peraturan perundang-undangan;
c. terdapat hal tertentu; dan
d. objek transaksi tidak boleh bertentangan dengan peraturan perundang- undangan, kesusilaan, dan ketertiban umum."

\section{Sedangkan dalam Pasal 18 ayat (1) UU ITE diatur bahwa:}

“Transaksi Elektronik yang dituangkan ke dalam Kontrak Elektronik mengikat para pihak."

UU No. 11 Tahun 2008 tentang Informasi dan Transaksi Elektronik dan UU No. 19 Tahun 2016 tentang Perubahan atas UU No. 11 Tahun 2008 tentang Informasi dan Transaksi Elektronik atau yang juga dikenal sebagai UU ITE merupakan suatu perundang-undangan yang cukup baru. UU ITE tidak secara spesifik mengatur tentang hak dan kewajiban produsen dan konsumen e-commerce, melainkan UU ini lebih berfokus dalam memberikan kepastian hukum serta perlindungan hukum bagi pengguna maupun provider internet secara umum. Meskipun begitu, UU ITE tetap dapat dijadikan salah satu sumber perundangan yang penting untuk transaksi e-commerce di Indonesia ${ }^{28}$.

Terkait dengan penggunaan internet, yang merupakan pemanfaatan dari teknologi informasi dan transaksi elektronik, oleh karena itu harus dilakukan sesuai dengan Pasal 3 UU ITE ${ }^{29}$.

Dalam Pasal 3 UU ITE diatur bahwa:

"Pemanfaatan teknologi informasi dan transaksi elektronik dilaksanakan berdasarkan asas kepastian hukum, manfaat, kehati-hatian, iktikad baik, dan kebebasan memilih teknologi atau netral teknologi."

Dengan semakin berkembangnya perdagangan yang dilakukan secara online, tentunya akan mengakibatkan timbulnya akibat-akibat hukum, salah satunya terkait pelanggaran terhadap asas iktikad baik yang dilakukan oleh para pihak yang bersepakat. Konsekuensi dari adanya iktikad yang tidak baik dalam perjanjian jual beli online, yaitu dapat berakibat dituntutnya pihak yang beriktikad tidak baik tersebut tidak hanya secara perdata, namun dapat juga di bawah ke ranah hukum pidana, dikaitkan dengan kasus penipuan ${ }^{30}$.

Penyelenggara agen elektronik wajib memperhatikan prinsip yang terdapat dalam Pasal 39 ayat (1) Peraturan Pemerintah No. 71 Tahun 2019 tentang Penyelenggaraan Sistem dan

${ }^{28}$ Reggiannie Christy Natalia, "Perlindungan Hukum Bagi Konsumen Toko Online Di Media Sosial," Law Review XVIII, no. 3 (2019): 72-89, https:// doi.org/10.19166/lr.v18i3.1407, h. 79.

${ }^{29}$ Dhaniar Eka Budiastanti, "Perlindungan Hukum Terhadap Korban Tindak Pidana Penipuan Melalui Internet," Jurnal Cakrawala Hukum 8, no. 1 (2017): 22-32, https://doi.org/10.26905/idjch.v8i1.1727, h. 25.

30 I Gede Krisna Wahyu Wijaya and Nyoman Satyayudha Dananjaya, "Penerapan Asas Itikad Baik Dalam Perjanjian Jual Beli Online," Kertha Semaya: Journal Ilmu Hukum 6, no. 8 (2018): 1-15, https://ojs.unud.ac.id/index.php/kerthasemaya/article/view/37212, h. 9. 
Transaksi Elektronik (PP PSTE) diatur bahwa:

a) kehati-hatian;

b) pengamanan dan terintegrasinya sistem teknologi informasi;

c) pengendalian pengamanan atas aktivitas transaksi elektronik;

d) efektivitas dan efisiensi biaya;

e) tanggung Jawab Penyelenggara Transaksi Elektronik; dan

f) perlindungan konsumen sesuai dengan ketentuan peraturan perundang undangan.

Pelaksanannya para pelaku atau penyelenggara sistem elektronik memiliki kewajiban seperti yang tertulis dalam Pasal 15 UU ITE diatur bahwa:

1) "Setiap Penyelenggara Sistem Elektronik harus menyelenggarakan Sistem Elektronik secara andal dan aman serta bertanggung jawab terhadap beroperasinya Sistem Elektronik sebagaimana mestinya;

2) Penyelenggaraan Sistem Elektronik bertanggung jawab terhadap Penyelenggaraan Sistem Elektroniknya;

3) Ketentuan sebagaimana di maksud pada ayat (2) tidak berlaku dalam hal dibuktikan terjadinya keadaan memaksa, kesalahan, dan/atau kelalaian pihak pengguna Sistem Elektronik."

Bagi para pengguna yang memanfaatkan situs forum atau web untuk melakukan penipuan dengan cara memberikan informasi palsu dan melakukan serangkaian kebohongan untuk membeli suatu produk yang ditawarkan, dalam hal ini berarti telah melakukan tindak pidana penipuan dan melanggar ketentuan dalam Pasal 28 ayat (1) UU ITE, yang diatur sebagai berikut:

"Setiap orang dengan sengaja dan tanpa hak menyebarkan berita bohong dan menyesatkan yang mengakibatkan kerugian konsumen dalam Transaksi Elektronik."

Dalam Pasal 45 ayat (1) dan (2) Peraturan Pemerintah Republik Indonesia Nomor 71 Tahun 2019 Tentang Penyelenggaraan Sistem dan Transaksi Elektronik diatur bahwa:

1) “Transaksi Elektronik yang dilakukan para pihak memberikan akibat hukum kepada para pihak;

2) Penyelenggaraan Transaksi Elektronik yang dilakukan para pihak wajib memperhatikan:
a) iktikad baik;
b) prinsip kehati-hatian;
c) transparansi;
d) akuntabilitas; dan
e) kewajaran."

Menurut analisis penulis, untuk mengantisipasi, mengoptimalkan atau menekan terjadinya persoalan-persoalan hukum yang sering terjadi dalam jual beli online, utamanya masalah penipuan maka pelaku usaha maupun konsumen wajib mematuhi aturan UU ITE khususnya yang terdapat dalam Pasal 45 ayat (2) PP No 71 Tahun 2019, terutama wajib memperhatikan iktikad baik dalam transaksi jual beli online dan prinsip kehati-hatian, sehingga perjanjian jual beli online tidak rawan terjadinya penipuan. Masalah iktikad baik ini sangat wajib diperhatikan oleh para pihak dalam jual beli online karena apabila salah satu pihak tidak mempunyai iktikad baik maka memunculkan akibat hukum, yaitu rawan terjadinya wanprestasi maupun penipuan. 
Pendapat penulis di atas, dikuatkan pula dalam Pasal 17 UU ITE diatur bahwa:

1) "Penyelenggaraan Transaksi Elektronik dapat dilakukan dalam lingkup publik ataupun privat.

2) Para pihak yang melakukan Transaksi Elektronik sebagaimana dimaksud pada ayat (1) wajib beriktikad baik dalam melakukan interaksi dan/atau pertukaran Informasi Elektronik dan/atau Dokumen Elektronik selama transaksi berlangsung.

3) Ketentuan lebih lanjut mengenai penyelenggaraan Transaksi Elektronik sebagaimana dimaksud pada ayat (1) diatur dengan Peraturan Pemerintah."

Transaksi Elektronik diatur dalam UU ITE mulai dari Pasal 17 - 22. Penipuan transaksi elektronik tidak dimuat secara eksplisit dalam UU ITE ini. Akan tetapi, pelaku dapat dikenakan Pasal 28 ayat (1) yang diatur bahwa "Setiap orang dengan sengaja dan tanpa hak menyebarkan berita bohong dan menyesatkan yang mengakibatkan kerugian konsumen dalam Transaksi Elektronik", "diancam dengan pidana penjara paling lama 6 (enam) tahun dan/atau denda paling banyak Rp. 1.000.000.000,00 (satu miliar rupiah)." Alat bukti penyidikan, penuntutan dan pemeriksaan di sidang pengadilan menurut ketentuan undangundang ini adalah alat bukti sebagaimana dimaksud dalam ketentuan perundang-undangan dan alat bukti lain berupa Informasi Elektronik dan/atau Dokumen Elektronik ${ }^{31}$.

Di mana unsur-unsur suatu perbuatan penipuan ditegaskan di dalam Pasal 28 ayat (1) UU ITE yang diatur bahwa:

"Setiap orang dengan sengaja dan tanpa hak menyebarkan berita bohong dan menyesatkan yang mengakibatkan kerugian konsumen dalam transaksi elektronik."

Menurut analisis penulis, unsur objektif Pasal 28 ayat (1) UU ITE yaitu perbuatan menyebarkan; dan mengakibatkan kerugian konsumen dalam transaksi elektronik. Sedangkan unsur subjektif Pasal 28 (1) UU ITE yaitu dengan sengaja; dan tanpa hak (melawan hukum).

Sedangkan mengenai Pasal 28 ayat (1) UU ITE di atas, ketentuan pidananya dapat dilihat dalam Pasal 45A ayat (1) diatur bahwa:

"Setiap orang yang memenuhi unsur sebagaimana dimaksud dalam Pasal 28 ayat (1) atau ayat (2) dipidana dengan pidana penjara paling lama 6 (enam) tahun dan/atau denda paling banyak Rp. 1.000.000.000,00 (satu miliar rupiah)."

Menurut analisis penulis, walaupun masalah perjanjian jual beli melalui transaksi elektronik telah memiliki kepastian hukum, sebagaimana diketahui pengaturan tentang transaksi elektronik yang diatur dalam UU No. 11 Tahun 2008 tentang Informasi dan Transaksi Elektronik dan UU No. 19 Tahun 2016 tentang Perubahan atas UU No. 11 Tahun 2008 tentang Informasi dan Transaksi Elektronik sebagai dasar utama pengaturan jual beli online dan PP Nomor 71 Tahun 2019 tentang Penyelenggaraan Sistem dan Transaksi Elektronik, Akan tetapi, meskipun dengan adanya pengaturan hukum tersebut tetapi fakta di masyarakat masih ditemukan rawan terjadinya penipuan dalam jual beli online. Karena penegak hukum belum cukup mampu menerapkan dengan baik pengaturan hukum tersebut untuk mengantisipasi, mengoptimalkan atau menekan terjadinya persoalan-persoalan hukum yang sering terjadi dalam jual beli online, yaitu utamanya persoalan penipuan dalam jual beli

31 Jevlin Solim et al., “Upaya Penanggulangan Tindak Pidana Penipuan Situs Jual Beli Online Di Indonesia,” Jurnal Hukum Samudra Keadilan 14, no. 1 (2019): 96-109, https:/ /doi.org/10.33059/jhsk.v14i1.1157, h. 101.

50 | B A L OBE Law Journal Vol. 1 No. 1, April 2021 
online yang masih rawan terjadinya penipuan. Hal ini diungkapkan penulis berdasarkan masalah-masalah hukum dalam jual beli online yang masih sangat rawan terjadinya penipuan.

Contoh kasus pertama, kasus penipuan perjanjian jual beli online adalah kasus yang terjadi di Kabupaten Barru Provinsi Sulawesi Selatan pada tahun 2020, di mana dalam kronologis kasusnya korban F dan pelaku NBH telah melakukan kesepakatan lewat media online untuk transaksi jual beli masker sensi yang telah diunggah pelaku lewat aplikasi media sosial facebook, kemudian pelaku dan korban mulai saling tawar menawar melalui aplikasi messenger, korban dan pelaku sepakat mengenai harga Rp. 170.000/box dengan memesan masker sebanyak 15 box dengan harga Rp. 2.550.000, kemudian korban chatting lagi lewat whatsApp dan pelaku mengirim nomor rekening ke korban. Akan tetapi, setelah korban mengirimkan uang terhadap si pelaku dengan lunas sesuai dengan harga barang yang dipesan, pada saat uang sampai di tangan pelaku, pelaku pun membuat paket berupa satu kotak berisi buku tulis dan handuk bayi bekas, dengan tampilan rapi kemudian pelaku menarik uang transfer Rp. 2.550.000 lalu menuju ke tempat pengiriman barang di Kota Parepare bersama istrinya, tidak berselang beberapa menit kemudian pelaku memblokir nomor whatsApp dan akun facebook korban, dalam kasus ini korban mengalami kerugian dan melaporkan kejadian ini ke Polres Kabupaten Barru dan dalam kasus ini pihak kepolisian telah berhasil mengungkap kasus penipuan perjanjian jual beli online dengan barang bukti yang diamankan satu buah handphone merek Oppo warna gold, satu kartu handphone, dos dengan tampilan rapi, buku, serta selimut bayi bekas dan uang Rp. 450.000,- berdasarkan alat bukti, saksi-saksi dan fakta-fakta hukum pelaku dijerat dugaan terpenuhi unsur penipuan Pasal 45A ayat (1) Undang-Undang Informasi dan Transaksi Elektronik (UU ITE) dengan ancaman pidana penjara paling lama 6 (enam) tahun dan/atau denda paling banyak Rp.1.000.000.000,00 (satu miliar rupiah) dan akan dikenakan Pasal 378 KUHPidana tentang penipuan dengan hukuman penjara 4 (empat) tahun. ${ }^{32}$

Menurut analisis penulis, berdasarkan kasus tersebut di atas, membuktikan bahwa dalam perjanjian jual beli online masih rawan terjadinya penipuan, sebagaimana pada kasus di atas, ditemukan di Kabupaten Barru Provinsi Sulawesi Selatan pada tahun 2020. Berdasarkan kronologis kasusnya korban F dan pelaku NBH telah melakukan kesepakatan lewat media sosial online untuk transaksi jual beli masker sensi telah diunggah pelaku lewat aplikasi media sosial facebook, korban pun memesan masker tersebut. Setelah korban mengirimkan uang terhadap si pelaku dengan lunas, namun setelah uang sampai di tangan pelaku, pelaku pun membuat paket berupa satu kotak berisi buku tulis dan handuk bayi bekas, dengan tampilan rapi kemudian pelaku menarik uang transfer Rp. 2.550.000 lalu menuju ke tempat pengiriman barang di Kota Parepare bersama istrinya, tidak berselang beberapa menit kemudian pelaku memblokir nomor whatsApp dan akun facebook korban, dalam kasus ini korban mengalami kerugian dan melaporkan kejadian ini ke Polres Kabupaten Barru dan dalam kasus ini pihak kepolisian telah berhasil mengungkap kasus penipuan perjanjian jual beli online dengan barang bukti yang diamankan satu buah handphone merek Oppo warna gold, kartu handphone satu, dos dengan tampilan rapi, buku, serta selimut bayi bekas dan uang Rp. 450.000,- berdasarkan alat bukti, saksi-saksi dan fakta-fakta hukum pelaku dijerat dugaan terpenuhi unsur penipuan Pasal 45A ayat (1) Undang-Undang Informasi dan Transaksi Elektronik (UU ITE) dengan ancaman pidana penjara paling lama 6 (enam) tahun dan/atau denda paling banyak Rp.1.000.000.000,00 (satu miliar rupiah) dan akan dikenakan Pasal 378

32 NewsMetropol, “Polres Barru Ungkap Kasus Penipuan Transaksi Jual Beli Online.” 
KUHPidana tentang penipuan dengan hukuman penjara 4 (empat) tahun.

Menurut analisis penulis, berdasarkan kasus di Kabupaten Barru yaitu kasus penipuan jual beli online lewat chatting media sosial facebook dan whatsApp yaitu jual beli online yang bukan salah satu perusahaan e-commerce, sehingga risiko terjadinya rawan penipuan sangat besar, masalah hukum yang terjadi dalam kasus di Kabupaten Barru yaitu penjual dan pembeli melakukan transaksi jual beli lewat online pelaku dan korban pun sepakat mengenai barang dan harga, Akan tetapi, pada saat penjual mengarahkan pembeli untuk mengirim uangnya pada saat uang sudah sampai di tangan pelaku kemudian pelaku mengirim barang tidak sesuai dengan yang disepakati, sehingga pembeli tidak memakainya, dalam kasus ini Polres Kabupaten Barru berdasarkan alat bukti, saksi-saksi dan fakta-fakta hukum pelaku dijerat dikenakan dugaan unsur penipuan Pasal 45A ayat (1) Undang-Undang Informasi dan Transaksi Elektronik (UU ITE) dengan ancaman pidana paling lama 6 (enam) tahun dan/atau denda paling banyak Rp.1.000.000.000,00 (satu miliar rupiah) dan akan dikenakan Pasal 378 KUHPidana tentang penipuan dengan hukuman penjara 4 (empat) tahun.

Contoh Kasus kedua, sekira-kiranya pada bulan Februari 2016 ditemukan di Kabupaten Sidrap Provinsi Sulawesi Selatan pada tahun 2016, Sub Direktorat Cyber Crime Dit Reserse Kriminal Khusus Polda Metro Jaya meringkus kelompok penipuan online dengan menggunakan akun palsu yang ada di beberapa toko online ternama di Indonesia, Kelompok tersebut membuat akun palsu di toko online, di antaranya olx.co.id, kaskus.co.id, bukalapak.com, tokopedia.com dan lain-lain, menurut keterangan Direktur Reskrimsus Polda Metro Jaya Komisaris Besar dalam keterangan pers di Mapolda Metro Jaya di mana ada sekelompok penipu yang berkedok menawarkan sepeda motor, jam tangan, batu akik, mobil dan telepon genggam melalui berbagai akun palsu di toko online akhirnya dibekuk polisi. Modusnya adalah setelah korban mentransfer uang, kelompok tersebut langsung mengambil uang dan barang yang dipesan oleh korban tidak dikirimkan, karena pada dasarnya barang tersebut tidak pernah ada, Lima orang diringkus, yakni H (34), AS (23), Z (49), R (33), dan B (32), kelimanya ditangkap di kawasan Sidrap Sulawesi Selatan. Selain tersangka polisi juga mengamankan sejumlah barang bukti kejahatan di antaranya 14 buah telepon genggam, 32 rekening berbagai bank, satu unit laptop, satu mobil Honda CRV, satu mobil Honda Freed, dan sebuah sepeda motor Yamaha, di mana total kerugian korban mencapai Rp. 10,1 Miliar, dalam kasus ini berdasarkan alat bukti, saksi-saksi dan fakta-fakta hukum, atas perbuatannya, para pelaku dijerat dugaan terpenuhi unsur penipuan Pasal 28 ayat (1) Undang-Undang Nomor 11 Tahun 2008 tentang Informasi dan Transaksi Elektronik Juncto Pasal 378 Kitab Undang-Undang Hukum Pidana tentang Penipuan, dan dijerat UU Tindak Pidana Pencucian Uang (TPPU) dengan ancaman kurungan di atas 15 (lima belas) tahun penjara. Penggunaan pasal berlapis ditujukan untuk menimbulkan efek jera. Karena selain kerugian materiel korban, kerugian immateriel berupa nama baik perusahaan menjadi tercemar sehingga kepercayaan pelanggan berkurang. ${ }^{33}$

Menurut analisis penulis, bahwa berdasarkan kasus Kabupaten Sidrap Provinsi Sulawesi Selatan yaitu kasus penipuan jual beli lewat toko online, dengan menggunakan akun palsu yang ada di beberapa toko online ternama di Indonesia, di antaranya olx.co.id, kaskus.co.id, bukalapak.com, tokopedia.com dan lain-lain, Kelompok tersebut membuat akun palsu mengatasnamakan toko online ternama di Indonesia, yaitu situs jual beli online yang bukan salah satu perusahaan e-commerce terkemuka di Indonesia karena akun palsu

\footnotetext{
33 Setyowati, Putra, and Saputro, "Perlindungan Hukum Pada Tindak Pidana E-Commerce." h. 220.
} 
walaupun menggunakan toko online ternama di Indonesia tetapi akun palsu yang tentunya tidak memiliki sistem yang terstruktur rapi untuk mencegah terjadinya rawan penipuan sehingga cenderung tidak terlalu aman terhadap penipuan. sehingga risiko terjadinya rawan penipuan sangat besar, perusahaan terkemuka perdagangan online (e-commerce) atau marketplace besar di Indonesia dengan akun palsu ini mengakibatkan berkurang kepercayaan masyarakat akibat akun palsu tersebut padahal marketplace terkemuka pada dasar tidak rawan penipuan karena memiliki sistem yang terstruktur dengan rapi untuk mencegah adanya unsur penipuan dalam jual beli online tersebut, dalam kasus ini berdasarkan alat bukti, saksisaksi dan fakta-fakta hukum, atas perbuatannya para pelaku dijerat dugaan terpenuhi unsur penipuan Pasal 28 ayat (1) Undang-Undang Nomor 11 Tahun 2008 tentang Informasi dan Transaksi Elektronik Juncto Pasal 378 Kitab Undang-Undang Hukum Pidana tentang Penipuan, dan dijerat UU Tindak Pidana Pencucian Uang (TPPU) dengan ancaman kurungan di atas 15 (lima belas) tahun penjara. Penggunaan pasal berlapis ditujukan untuk menimbulkan efek jera. Karena selain kerugian materiel korban, kerugian immateriel berupa nama baik perusahaan menjadi tercemar sehingga kepercayaan pelanggan berkurang.

Kasus penipuan yang kerap terjadi akhir-akhir ini seakan membuat resah masyarakat. Bagaimana tidak, berbagai cara dilakukan dalam aksi penipuan dan salah satunya adalah penipuan jual beli online yang kini marak dan rawan terjadi di dunia internet. Para pelaku penipuan pun tampaknya sudah tidak takut lagi dengan hukuman atau pidana yang dapat menjerat mereka apabila mereka terbukti melakukan kejahatan penipuan tersebut. Bahkan penipuan jual beli online semakin marak terjadi dengan cara-cara yang lebih canggih sehingga terkesan tidak meninggalkan bukti ${ }^{34}$.

Menurut analisis penulis, masalah-masalah hukum yang sering terjadinya dalam perjanjian jual beli online lewat transaksi elektronik, yaitu masih rawan terjadinya penipuan, karena dalam perjanjian jual beli online tidak dilakukan pertemuan secara langsung dalam transaksinya. Akan tetapi, dilakukan lewat media elektronik, masalah yang sering muncul, yaitu pembeli sudah membayar harganya tetapi penjual tidak mengirim barang sampai waktu yang lama bahkan tidak sampai, karena barang tersebut memang tidak pernah ada sebelumnya, barang yang sampai ke pembeli rusak atau tidak sebagaimana mestinya sehingga pembeli tidak memakainya. Berdasarkan masalah hukum tersebut di atas, tentunya dengan adanya kerugian yang dialami oleh pembeli maka akan memberikan konsekuensi hukum berupa tanggung jawab kepada penjual atas kerugian pembeli tersebut, baik tanggung jawab pidana (pidana penjara) maupun tanggung jawab denda sesuai dengan pengaturan UU ITE masalah akibat penipuan online.

Proses pelaksanaan transaksi jual beli lewat online (e-commerce) ini dilakukan dalam beberapa tahap, sebagai berikut: ${ }^{35}$

1) penawaran yang dilakukan oleh penjual atau pelaku usaha melalui website pada internet;

2) penerimaan, dapat dilakukan tergantung penawaran yang terjadi;

3) pembayaran, dapat dilakukan baik secara langsung maupun tidak langsung;

34 Wahyu Adi Susanto, Heni Hendrawati, and Basri, “Tinjauan Kriminologi Terhadap Tindak Pidana Penipuan Jual Beli Online," Varia Justicia 13, no. 1 (2017): 38-46, https:/ / doi.org/10.31603/variajusticia.v13i1.1864, h. $41-42$.

35 Sri Anggraini Kusuma Dewi, “Perjanjian Jual Beli Barang Melalui Elektronik Commerce (E-Com)," Jurnal Ilmiah Teknologi Dan Informasi Asia 9, no. 2 (2015): https://jurnal.stmikasia.ac.id/index.php/jitika/article/view/102, h. 3. 
4) pengiriman, merupakan suatu proses yang dilakukan setelah pembayaran atas barang yang ditawarkan penjual kepada pembeli, dalam hal ini pembeli berhak atas penerimaan barang tersebut.

\section{P E N U T U P}

Dari uraian hasil dan pembahasan di atas, akibat hukum terjadinya penipuan dalam perjanjian jual beli online dalam hukum positif Indonesia, yaitu menimbulkan tanggung jawab atas kerugian konsumen dalam transaksi atas kerugian konsumen mewajibkan orang yang karena salahnya menerbitkan kerugian itu, mengganti kerugian tersebut. Akibat penipuan jual beli online bukan hanya menimbulkan akibat hukum tetapi ke ranah hukum perdata maupun pidana. Maka rekomendasi penulis bisnis jual beli online bisa berjalan dengan baik apabila si pelaku usaha dan konsumen benar-benar jujur dalam bertransaksi jual beli online dan wajib memperhatikan, iktikad baik, prinsip kehati-hatian; transparansi; akuntabilitas; dan kewajaran dalam melakukan transaksi jual beli online tersebut, selain itu dalam melakukan transaksi jual beli online, untuk melakukan penyerahan barang yang dilakukan oleh pedagang dan penyerahan uang yang dilakukan oleh pembeli harus memiliki prinsip kehatian-hatian untuk mengantisipasi, mengoptimalkan atau menekan terjadinya unsur penipuan. Khusus untuk masyarakat harus memiliki prinsip kehati-hatian untuk melihat dengan cermat apakah melakukan perjanjian jual online lewat sebuah perusahaan e-commerce terkemuka di Indonesia baik Tokopedia, Lazada, Blibli.com, Bukalapak, Zalora, Shopee, Berrybenka, Kaskus dan Traveloka, yang tentunya perusahaan terkemuka perdagangan online (e-commerce) atau marketplace besar di Indonesia yang telah memiliki sistem yang terstruktur rapi untuk mencegah terjadinya rawan penipuan sehingga cenderung lebih aman, dibandingkan dengan jual beli online baik facebook, messenger, telegram, whatsApp, instagram, twitter, forum yang tentunya risiko sangat besar terjadi rawan penipuan karena situs jual beli online bukan sebuah perusahaan $e$-commerce terkemuka di Indonesia yang tentunya tidak memiliki sistem yang terstruktur rapi untuk mencegah terjadinya rawan penipuan sehingga cenderung tidak terlalu aman terhadap penipuan.

\section{REFERENSI}

Amiruddin, and Zainal Asikin. Pengantar Metode Penelitian Hukum. Jakarta: Raja Grafindo Persada, 2018.

Bintoro, Rahadi Wasi. "Penerapan Hukum Dalam Penyelesaian Sengketa Transaksi Elektronik Di Peradilan Umum." Jurnal Dinamika Hukum 11, no. 2 (2011): 258-72. https:// doi.org/10.20884/1.jdh.2011.11.2.185.

Buana, Andika Prawira, Hasnan Hasbi, Muhammad Kamal, and Aan Aswari. "Implikasi Pelaksanaan Perjanjian Jual Beli Telepon Seluler Ilegal (Black Market)." JCH (Jurnal Cendekia Hukum) 6, no. 1 (2020): 124-33. https:/ / doi.org/10.33760/jch.v6i1.287.

Budiastanti, Dhaniar Eka. "Perlindungan Hukum Terhadap Korban Tindak Pidana Penipuan Melalui Internet." Jurnal Cakrawala Hukum 8, no. 1 (2017): 22-32. https:// doi.org/10.26905/idjch.v8i1.1727.

Dewi, Sri Anggraini Kusuma. “Perjanjian Jual Beli Barang Melalui Elektronik Commerce (ECom)." Jurnal Ilmiah Teknologi Dan Informasi Asia 9, no. 2 (2015): 1-5. https://jurnal.stmikasia.ac.id/index.php/jitika/article/view/102.

Hamdi, Syaibatul, Suhaimi, and Mujibussalim. "Bukti Elektronik Dalam Sistem Pembuktian Pidana." Jurnal Ilmu Hukum 1, no. 4 (2013): 25-31. 
http://jurnal.unsyiah.ac.id/MIH/article/view/4564.

Irwansyah. Penelitian Hukum (Pilihan Metode E Praktik Penulisan Artikel). Yogyakarta: Mirra Buana Media, 2020.

Maskun. Kejahatan Siber Cyber Crime Suatu Pengantar. Jakarta: Kencana Prenada Media Group, 2013.

Maskun, Naswar, Ahmad, Hasbi Assidiq, Armelia Safira, and Siti Nurhalima Lubis. Korelasi Kejahatan Siber Dan Kejahatan Agresi Dalam Perkembangan Hukum Internasional. Makassar: Nas Media Pustaka, 2020.

Meliala, Aloina Sembiring. "Analisis Yuridis Terhadap Legalitas Dokumen Elektronik Sebagai Alat Bukti Dalam Penyelesaian Sengketa." Jurnal Wawasan Yuridika 32, no. 1 (2015): 99_ 111. https://doi.org/10.25072/jwy.v32i1.92.

Miru, Ahmadi. Hukum Kontrak \& Perancangan Kontrak. Jakarta: Rajawali Pers, 2018.

Miru, Ahmadi, and Sakka Pati. Hukum Perjanjian (Penjelasan Makna Pasal-Pasal Perjanjian Bernama Dalam BW). Jakarta: Sinar Grafika, 2020.

Muljadi, Kartini, and Gunawan Widjaja. Perikatan Yang Lahir Dari Perjanjian. Jakarta: Rajawali Pers, 2014.

Mustarin, Basyirah. "Tinjauan Hukum Nasional Dan Hukum Islam Terhadap Konsumen Pengguna Jasa Jual Beli Online." Jurnal Restorative Justice 1, no. 2 (2017): 132-45. https:// doi.org/10.35724/jrj.v1i2.1915.

Natalia, Reggiannie Christy. "Perlindungan Hukum Bagi Konsumen Toko Online Di Media Sosial." Law Review XVIII, no. 3 (2019): 72-89. https:/ / doi.org/10.19166/lr.v18i3.1407.

Nawi, Syahruddin. Penelitian Hukum Normatif Versus Penelitian Hukum Empiris. Makassar: Umitoha Ukhuwah Grafika, 2018.

NewsMetropol. "Polres Barru Ungkap Kasus Penipuan Transaksi Jual Beli Online." newsmetropol.com, 2020. https://newsmetropol.com/polres-barru-ungkap-kasuspenipuan-transaksi-jual-beli-online/\#.

Putra, S. “Perlindungan Hukum Terhadap Konsumen Dalam Transaksi Jual-Beli Melalui ECommerce." Jurnal Ilmu Hukum 4, no. 1 (2014): 287-308. https:/ / media.neliti.com/media/ publications/9164-ID-perlindungan-hukumterhadap-konsumen-dalam-transaksi-jual-beli-melalui-e-commerc.pdf.

Qamar, Nurul, Muhammad Syarif, Dachran S Busthami, M Kamal Hidjaz, Aan Aswari, Hardianto Djanggih, and Farah Syah Rezah. Metode Penelitian Hukum (Legal Research Methods). Makassar: Social Political Genius, 2017.

Salim, HS. Teknik Pembuatan Akta Perjanjian (TPA Dua). Jakarta: Rajawali Pers, 2018.

Setyowati, Dewi, Candra Pratama Putra, and Ramdhan Dwi Saputro. "Perlindungan Hukum Pada Tindak Pidana E-Commerce." Perspektif Hukum 18, no. 2 (2019): 215-46. https:// doi.org/10.30649/phj.v18i2.160.

Soekanto, Soerjono, and Sri Mamudji. Penelitian Hukum Normatif, Suatu Tinjauan Singkat. Jakarta : Raja Grafindo Persada. Jakarta: Rajawali Pers, 2015.

Solim, Jevlin, Mazmur Septian Rumapea, Agung Wijaya, Bella Monica Manurung, and Wendy Lionggodinata. "Upaya Penanggulangan Tindak Pidana Penipuan Situs Jual Beli Online Di Indonesia." Jurnal Hukum Samudra Keadilan 14, no. 1 (2019): 96-109. https:// doi.org/10.33059/jhsk.v14i1.1157. 
Sukarmi, and Yudhi Tri Permono. "Perlindungan Hukum Konsumen Dalam Transaksi Secara Online." Jurnal Hukum 35, no. 1 (2019): 77-100. https:/ / doi.org/10.26532/jh.v35i1.11046.

Susanto, Wahyu Adi, Heni Hendrawati, and Basri. “Tinjauan Kriminologi Terhadap Tindak Pidana Penipuan Jual Beli Online." Varia Justicia 13, no. 1 (2017): 38-46. https:// doi.org/10.31603/variajusticia.v13i1.1864.

Wijaya, I Gede Krisna Wahyu, and Nyoman Satyayudha Dananjaya. "Penerapan Asas Itikad Baik Dalam Perjanjian Jual Beli Online." Kertha Semaya: Journal Ilmu Hukum 6, no. 8 (2018): 1-15. https://ojs.unud.ac.id/index.php/kerthasemaya/article/view/37212.

Wulandari, Yudha Sri. "Perlindungan Hukum Bagi Konsumen Terhadap Transaksi Jual Beli E-Commerce." Ajudikasi: Jumal Ilmu Hukum 2, no. 2 (2018): 199-210. https:// doi.org/10.30656/ajudikasi.v2i2.687. 